\title{
Advantages of recovery from pre-slaughter stress in tambaqui Colossoma macropomum (Cuvier 1816) agroindustry in the Amazon
}

\author{
Joana Maia MENDES ${ }^{1}$, Jony Koji DAIRIKI², Luis Antonio Kioshi Aoki INOUE³, Rogério Souza de JESUS ${ }^{4 *}$
}

\begin{abstract}
Tambaqui is the main fish species farmed in the Amazon. It is produced on industrial scale, slaughtered in the field, primarily by post-harvest asphyxia. This procedure, however, is stressful because it depletes energy reserves that should be used in postmortem metabolism, which may compromise fish meat freshness and quality. The present study compared the quality of tambaquis slaughtered by asphyxia, the conventional industrial method, and hypothermia. Tambaquis weighing around $1.6 \mathrm{~kg}$ were harvested from dugout ponds, transported to experimental tanks and allowed to recover from transport stress for $48 \mathrm{~h}$. Biological parameters of fish were evaluated alive post- harvest (Harv), transport (Tr) and recovery (Rc), and postmortem analysis was performed in fish slaughtered by asphyxia (Asph) or hypothermia (Hyp) after transport and recovery. Initial observations showed that the content of total volatile nitrogen bases (TVB-N) and $\mathrm{pH}$ were higher in fish killed by asphyxia. Sensory analysis indicated that the quality of fish slaughtered immediately after transport was lower than in fish allowed to recover from pre-slaughter stress. The results suggest that recovery from pre-slaughter stress contributes to preserving meat freshness and quality in tambaquis slaughtered on an industrial scale, but other studies are required to determine the feasibility of this recommendation.
\end{abstract}

Keywords: stress; management practices; fish processing.

Practical Application: This study contributes to the adoption of practices that promote humanitarian management.

\section{Introduction}

Tambaqui is the main fish species reared in the Amazon. It exhibits desirable farming characteristics, such as consuming artificial feed and exhibiting satisfactory growth rates and food conversion indexes. In addition, its rusticity is particularly important in waters with low levels of dissolved oxygen and high temperatures. Tambaqui is one of the most commonly consumed species in Amazonian fish markets, especially in Manaus, the largest urban center, and projections indicate growth in both regional and global demand (Freitas et al., 2014). Therefore, the industrial production of tambaquis for export markets is expected to increase, requiring proper quality control throughout the productive cycle, especially in fish transport from the field to the industrial plant.

The main method used to slaughter farmed tambaquis is post-harvest asphyxia, after which fish are transported in ice-filled containers directly to the market or industrial plant. According to a number of authors (Acerete et al., 2009; Gatica et al., 2010; Viegas et al., 2012; Oliveira et al., 2015), this procedure is inadequate because to cope with stress incurred before and during the ordeal, fish deplete energy reserves that should be used in postmortem metabolism, which may compromise the preservation of meat freshness and quality. The present study evaluated pre-slaughter tambaqui response to stress and assessed the consequences in fish slaughtered by asphyxia or hypothermia, storing fish in ice and accompanying rigor mortis and changes in quality parameters. The information obtained will be useful for both industry and the fresh meat market, which consumes fish stored in ice.

\section{Material and methods \\ 2.1 Test fish}

One hundred and twenty juvenile tambaquis (Colossoma macropomum) with mean weight $246 \pm 58 \mathrm{~g}$ and mean length $25 \pm 2 \mathrm{~cm}$, from the Fish Culture Station of Balbina (AM) were stocked in $1000 \mathrm{~m}^{2}$ dugout pond at the Western Amazon Embrapa (Brazilian Corporation of Agricultural Research) facilities for 9 months. The water column was kept level by replacing losses from evaporation and infiltration. Fish were fed to apparent satiation twice a day until they reached around $1.6 \mathrm{~kg}$ body weight. The commercial feed used contained $28 \%$ crude protein. Feeding stopped 2 days before fish were harvested with a $25 \mathrm{~mm}$-mesh fishing net.

\subsection{Experimental design}

During harvest, 6 fish randomly collected from the fishing net were used for blood sampling (Harv. group). The remaining fish were placed in a 1000-L tank supplied with an air stone and 
oxygen regulator coupled to a cylinder and transported by truck for nearly $2 \mathrm{~h}$ to the Aquaculture Station of the National Institute of Amazon Research (INPA). Immediately upon arrival, 6 fish were rapidly removed from the transport tank with a dip net for blood sampling (Tr group); 18 fish were collected and slaughtered by hypothermia, in an ice bath (Tr/Hyp group); and 18 were slaughtered by asphyxia, in a polystyrene foam container placed in a shaded area ( $\mathrm{Tr} / \mathrm{Asph}$ group). Six fish from each group were used for blood analysis, 5 to investigate for rigor mortis and 7 for sensory analysis, and to determine $\mathrm{pH}$ and total volatile nitrogen bases (TVB-N). The remaining fish were held in circular 5000L-glass fiber tanks, supplied with water in a closed system with continuous aeration, for $48 \mathrm{~h}$ to allow recovery from pre-slaughter stress. Following recovery, 6 fish were rapidly collected with a dip net for biological material sampling (Rc group), 18 were slaughtered by hypothermia (Rc/Hyp group) and 18 by asphyxia (Rc/Asph group). The same physiological parameters analyzed for fish slaughtered before recovery were evaluated in post-recovery fish. The remaining fish were released into a dugout pond at the aquaculture station to be used as breeders.

\subsection{Blood analysis and stress evaluation}

Fish blood sampled at each management phase (Harv, Tr and Rc groups) were collected from the caudal vein with syringes rinsed with 3\% EDTA. Blood taken from 6 fish of each group (Tr/Hyp, Tr/Asph, Rc/Hyp and Rc/Hyp), immediately after their death, was analyzed for illustration purposes and not for statistical comparison with that of live fish. Blood samples were centrifuged at $12000 \mathrm{~g}$ for $3 \mathrm{~min}$ to separate serum, which was stored at $-20{ }^{\circ} \mathrm{C}$ until they were analyzed. Serum samples were used to determine cortisol using the ELISA kit, glucose (Trinder, 1969), lactate (Harrower \& Brown, 1972), protein (Lowry et al., 1951), ammonia (Gentzkow \& Masen, 1942), sodium and potassium (flame photometer) and plasma chloride (American Public Health Association, 1980).

\subsection{Rigor mortis}

After death was confirmed, the fish were taken to the Fishery Technology Laboratory of INPA and kept in ice in polystyrene foam boxes. Five fish from each slaughter method (hypothermia or asphyxia) and management phase (post-transport and post-recovery) were separated for rigor mortis examination. The specimens were identified with label strings and kept in ice. The progression of rigor mortis was observed immediately after slaughter and every $15 \mathrm{~min}$ to determine the time of rigor onset and to monitor it until it reached maximum stiffness (100\%). After reaching $100 \%$ rigor, dead fish were checked daily until rigor resolution. Rigor index was measured from body flexion. To that end, each fish was placed on a flat-surfaced table, fixing the body from the head to the pelvic fin and setting the posterior portion of the body free. The length of body flexion in relation to the flat surface was measured with a ruler and set square, as described by Bito et al. (1983).

\subsection{Fish quality}

Sensory analysis evaluated 7 fish killed by each slaughter method and sampling phase (Tr/Asph, Tr/Hyp, Rc/Asph and $\mathrm{Rc} / \mathrm{Hyp}$ ). After slaughter, fish were kept in ice until muscle $\mathrm{pH}$ and total volatile nitrogen bases (TVB-N) were measured every seven days, for 49 days. Physical sensory analysis was performed by a trained panel that evaluated changes in the general appearance of the fish (skin, scales, texture, stiffness, elasticity and odor), eyes (transparence and shape) and gills (color and odor). Sensory analysis was performed according to the Quality Index Method (QIM), using a sensory evaluation table modified according to Larsen et al. (1992) and Herrero et al. (2003). Each attribute was scored, and specimens were classified in accordance with their total scores. The maximum score was 16 and indicated that the fish was unsuitable for consumption.

Muscle $\mathrm{pH}$ was determined in triplicate. To that end, $10 \mathrm{~g}$ of skinned muscle from each specimen was ground and homogenized with $100 \mathrm{~mL}$ of distilled water and the solution was read in a digital $\mathrm{pH}$ meter. For TVB-N determination, also in triplicate, $10 \mathrm{~mL}$-aliquots of ground muscle samples were placed into micro Kjeldahl distillation flasks coupled to a distillation set and boiled for $8 \mathrm{~min}$. The distillate was transferred to a $4 \%$ boric acid solution and added with methyl red and bromocresol green indicators. The bases were titrated with $0.02 \mathrm{M}$ chloride acid solution. The procedures were performed according to the Manual of Analytical Methods of the Instituto Adolfo Lutz (2008).

\subsection{Ethical and legal aspects}

The study was approved by the Animal Experimentation Ethics Committee of the National Institute of Amazonian Research (CEUA/INPA, protocol 073/2012).

\subsection{Statistical analysis}

Data were analyzed using ANOVA, and significant differences between means were contrasted by the Tukey test. The significance level was set at a p-value of 0.05 .

\section{Results}

No fish mortality was observed as a function of management practices used (harvesting, transport and recovery). An increase in cortisol levels was observed in fish sampled after harvest (Harv) and transport ( $\mathrm{Tr}$ ), and a decrease in fish allowed 48h-recovery (Rc). Glucose levels were high after $2 \mathrm{~h}$ transport ( $\mathrm{Tr})$, and lactate levels were high after harvest (Harv) and slightly lower after transport ( $\mathrm{Tr}$ ) and recovery $(\mathrm{Rc})$. Plasma ammonia was high after transport (Tr), and low in protein and plasma chloride. Plasma sodium was high after transport (Tr) and lower after 48h-recovery (Rc).

Low cortisol levels were detected in groups slaughtered by asphyxia ( $\mathrm{Tr} / \mathrm{Asph}$ and Rc/Asph). Tr/Hyp fish exhibited higher plasma parameter values, especially cortisol and glucose, compared to their Harv counterparts. Rc/Hyp fish also showed higher blood parameter values compared to those of Harv, especially cortisol (Figure 1 and Table 1).

Fish from the different groups reached $100 \%$ rigor mortis at different times: $1 \mathrm{~h}$ in $\mathrm{Tr} / \mathrm{Asph}$; $1: 15 \mathrm{~h}$ in Tr/Hyp; $2 \mathrm{~h}$ in Rc/Asph and $4 \mathrm{~h}$ in Rc/Hyp. It is important to highlight that fish slaughtered both after transport and recovery took $3 \mathrm{~h}$ to die from asphyxia and only $10 \mathrm{~min}$ from hypothermia. Rigor mortis resolution was 
Table 1. Plasma $\mathrm{Na}, \mathrm{Cl}, \mathrm{K}$, protein and ammonia levels in tambaquis subjected to pre slaughtering harvest (Harv), transport ( $\mathrm{Tr}$ ) and post-transport recovery (Rc) and after slaughtering by asphyxia (Asph) or hyporthemia (Hyp).

\begin{tabular}{|c|c|c|c|c|c|}
\hline & \multicolumn{3}{|c|}{$\mathrm{mEq} / \mathrm{L}$} & \multirow{2}{*}{$\frac{\mathrm{g} / \mathrm{dL}}{\text { protein }}$} & \multirow{2}{*}{$\frac{\mathrm{umol} / \mathrm{mL}}{\mathrm{ammonia}}$} \\
\hline & $\mathrm{Na}$ & $\mathrm{Cl}$ & $\mathrm{K}$ & & \\
\hline Harv $^{1}$ & $46 \pm 9$ & $113 \pm 6$ & $2 \pm 1$ & $3 \pm 1$ & $2.6 \pm 0.3^{\mathrm{a}}$ \\
\hline $\operatorname{Tr}^{1}$ & $49 \pm 7$ & $107 \pm 7$ & $2 \pm 1$ & $3 \pm 1$ & $3.2 \pm 0.3^{b}$ \\
\hline $\operatorname{Tr} /$ Asp & $47 \pm 5$ & $86 \pm 19$ & $1 \pm 0$ & $3 \pm 1$ & $4.1 \pm 0.3$ \\
\hline Tr/Hyp & $62 \pm 8$ & $101 \pm 19$ & $2 \pm 1$ & $3 \pm 0$ & $3.7 \pm 0.4$ \\
\hline $\mathrm{Rc}^{1}$ & $41 \pm 6$ & $118 \pm 2$ & $1 \pm 1$ & $4 \pm 1$ & $3.1 \pm 0.3^{\mathrm{a}}$ \\
\hline Rc/Asph & $49 \pm 8$ & $112 \pm 8$ & $1 \pm 0$ & $3 \pm 1$ & $5.0 \pm 1.0$ \\
\hline Rc/Hyp & $108 \pm 19$ & $116 \pm 7$ & $5 \pm 1$ & $3 \pm 1$ & $3.2 \pm 0.4$ \\
\hline
\end{tabular}

${ }^{1}$ Different superscript letters in a column indicate significant differences among treatments with live fish (Harv, Tr, Rc) (ANOVA, $\mathrm{p}<0.05)$.
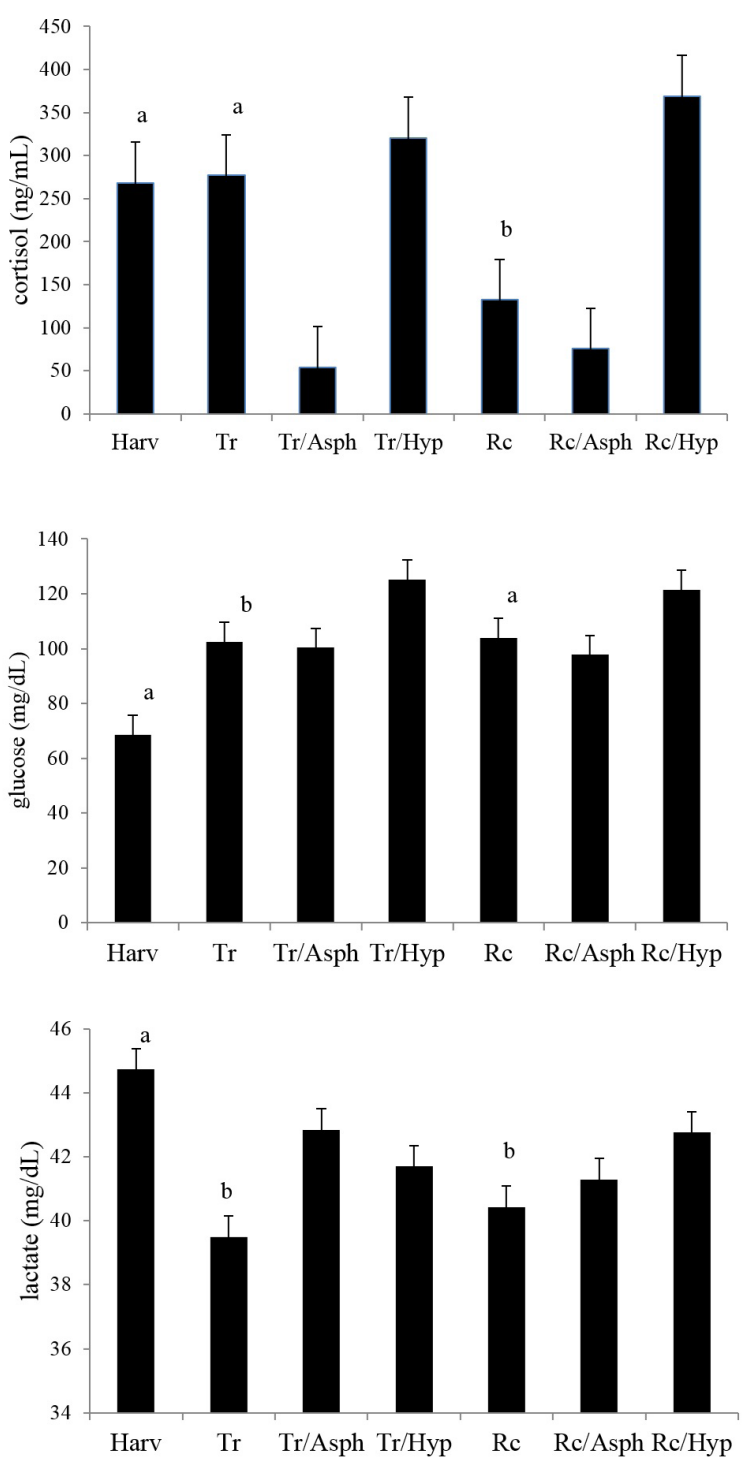

Figure 1. Cortisol, glucose and lactate levels in tambaquis after pre-slaughter harvest (Harv), transport (Tr) and recovery (Rc) and slaughter by asphyxia (Asph) or hypothermia (Hyp). Different letters indicate a significant difference $(p<0.05)$ between the treatments with live fish (Harv, $\mathrm{Tr}, \mathrm{Rc}$ ), before slaughtering. observed after 11 days in $\mathrm{Tr} / \mathrm{Asph}, 20$ days in Tr/Hyp, 18 days in Rc/Asph and 30 days in Rc/Hyp (Table 2).

Muscle $\mathrm{pH}$ did not show significant variations as a function of slaughter method, although a slight $\mathrm{pH}$ increase was detected in fish subjected to hypothermia. On the other hand, fish slaughtered after transport exhibited $\mathrm{pH}$ above 6.5 at 28 days post-slaughter, while those allowed stress recovery reached a $\mathrm{pH}$ of 6.4 after 42 days. After recovery, fish slaughtered by asphyxia or hyperthermia showed $\mathrm{pH}$ above 6.5 at 49 days post-slaughter (Figure 2).

In sensory analysis, the scores for $\mathrm{Tr} / \mathrm{Asph}$ fish increased at the beginning of observations. From 21days post-slaughter onward, Tr/Hyp scores resembled those of Tr/Asph, and both
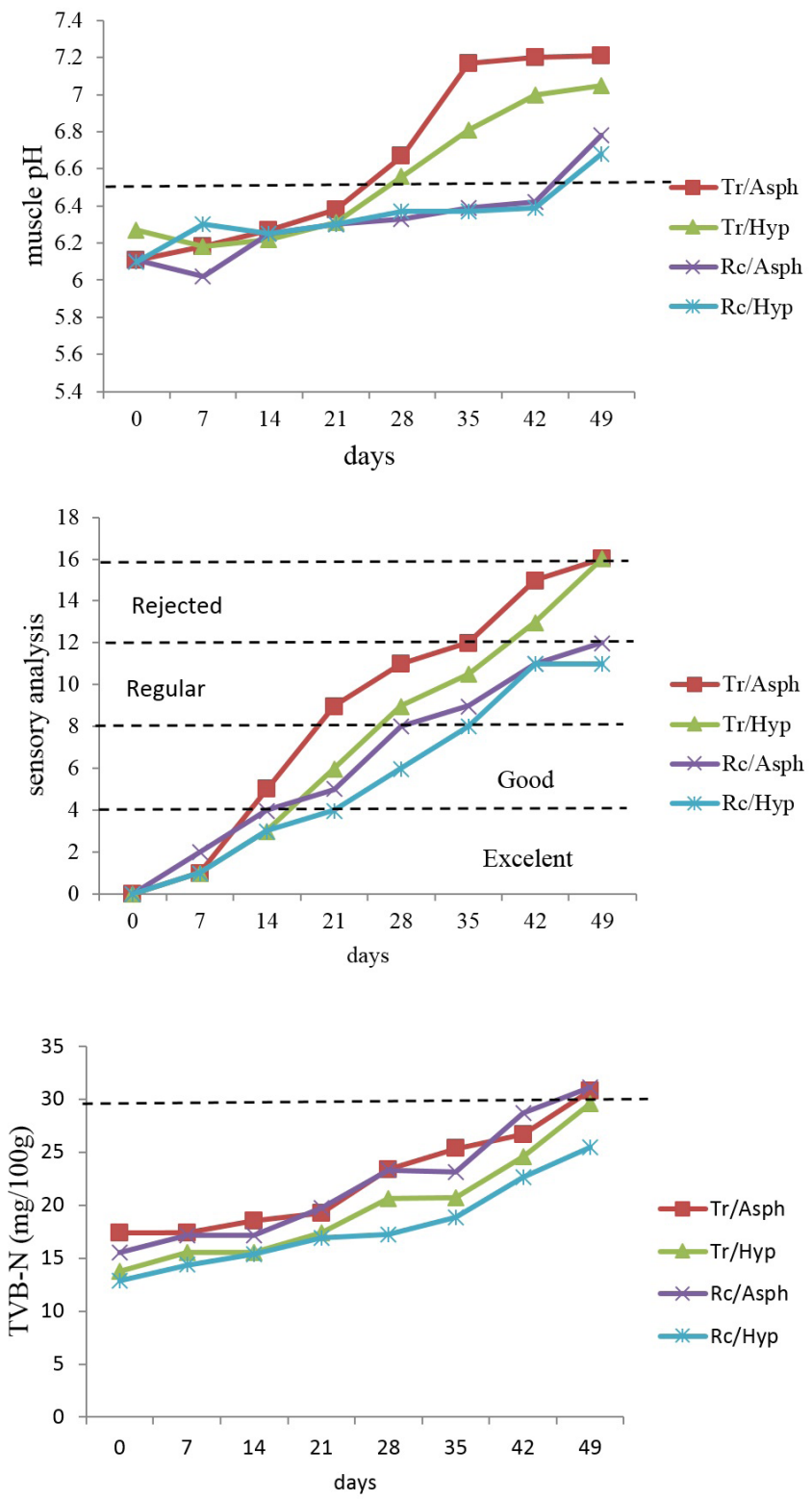

Figure 2. Muscle $\mathrm{pH}$, sensory analysis and total volatile nitrogen bases (TVB-N) in tambaquis stored in ice. Fish were slaughtered by asphyxia (Asph) or hyperthermia (Hyp) after subjected to transport stress (Tr) and $48 \mathrm{~h}$ recovery $(\mathrm{Rc})$. 
Table 2. Rigor mortis of tambaquis slaughtered after transport (Tr) stress and recovery $(\mathrm{Rc})$. Fish were slaughtered by asphyxia (Asph) or hypothermia (Hyp).

\begin{tabular}{ccc}
\hline \multirow{2}{*}{ Slaughter Mode } & \multicolumn{2}{c}{ Rigor mortis } \\
\cline { 2 - 3 } & Onset (h) & Resolution (days) \\
\hline Tr/Asph & $1: 00^{\mathrm{a}}$ & $11^{\mathrm{a}}$ \\
Tr/Hyp & $1: 15^{\mathrm{a}}$ & $20^{\mathrm{b}}$ \\
Rc/Asph & $2: 00^{\mathrm{b}}$ & $18^{\mathrm{b}}$ \\
Rc/Hyp & $4: 00^{\mathrm{c}}$ & $30^{\mathrm{c}}$ \\
\hline
\end{tabular}

Different superscript letters in a column indicate significant differences among treatments (ANOVA, p < 0.05)

reached the maximum level of 16 points at 49 days post-slaughter (Figure 2). Rc/Asph fish also showed a more pronounced score progression at the beginning of observations. At 42 days post-slaughter, Rc/Asph and Rc/Hyp fish obtained the same scores. At the end of observations (49 days post-slaughter), fish that underwent recovery were still suitable for consumption, irrespective of the slaughter method.

The TVB-N levels indicated lower quality in fish slaughtered by asphyxia, since these fish were kept in ice until the end of observations (49 days), when the limit established by RIISPOA (30 $\mathrm{g} \mathrm{kg}^{-1}$ TVB-N) was reached in both Tr/Asph and Tr/Hyp fish. On the other hand, Rc/Hyp showed acceptable TVB-N (25 $\mathrm{g} \mathrm{kg}^{-1}$ TVB-N) at 49 days post-slaughter (Figure 2).

\section{Discussion}

Although transport is the most stressful management practice for fish, it is necessary for hatchery operations (Gomes et al., 2003; Mendes et al., 2015). The tambaquis evaluated showed a stress response to transport, and were slaughter in that condition. Therefore, to neglect the pre-slaughter physiological condition of fish may compromise the quality of their meat, as described by Erikson et al. (2012). The stress condition begins as soon as the nervous system detects one or more adverse stimuli that can impair animal equilibrium with the environment. Two physiological axes are activated, the brain-pituitary-interrenal axis and the brain-sympathetic chromaffin cell axis. Cortisol and catecholamines are released into the blood stream and start the metabolic production of extra energy for escape or adaptation to farming conditions (Iwama et al., 2004). As a result, fish slaughtered just after transport show lower quality (Viegas et al., 2012) in terms of the stress indicators evaluated (plasma cortisol, glucose, lactate, ammonia, protein, sodium, chloride and potassium) and rigor mortis development (Acerete et al., 2009; Mendes et al., 2015).

The most intense changes in stress indicators were observed in fish slaughtered post-transport and by asphyxia ( $\mathrm{Tr} / \mathrm{Asph}$ ). The $\mathrm{Tr} / \mathrm{Asph}$ fish dehydrated because of prolonged exposure to air, which led to an increase in plasma sodium and potassium levels and a decrease in chloride levels. Dehydration also increased plasma ammonia, since it cannot be excreted out of water. Plasma cortisol levels in fish subjected to asphyxia were very low, because chromaffin cells likely collapsed during the extended time required for death (3h). The high cortisol levels observed immediately after transport $(\mathrm{Tr})$ were probably metabolized, and the tambaquis did not release any more of this substance into the blood stream (by chromaffin cells) during exposure to air. The increase in plasma cortisol and glucose observed in tambaquis slaughtered by hypothermia, post-transport or post- recovery, confirms that fish slaughtered by asphyxia suffered from overall failure of chromaffin cells.

Rigor mortis initiates when muscle ATP falls to a critical level, and myofibrillar actin and myosin bind, forming actomyosin complexes that produce irreversible muscle contraction, which is the classic characteristic of this condition (Pate \& Brokaw, 1980; Knowles et al., 2008). In tambaquis, post-transport recovery seems to be necessary, given that fish slaughtered by hypothermia after recovery required $4 \mathrm{~h}$ to enter rigor mortis, whereas those killed post-transport took $1 \mathrm{~h}$ using asphyxia and 1:15h using hypothermia, also as obtained by Mendes et al. (2015). According to Boggess et al. (1973), the chemical reactions in muscle caused by pre-slaughter stress accelerate rigor mortis development in fish. Although the post-transport slaughter method also affected tambaqui rigor mortis, transport stress recovery is beneficial (Gatica et al., 2008) even for fish killed by hypothermia. Indeed, fish that underwent recovery achieved rigor resolution in 30 days, whereas those killed by post-transport asphyxia exhibited it in only 11 days.

Muscle glycogen reserves in fish under stressful conditions such as transport usually decline due to excessive locomotion of animals attempting to escape, reducing post-mortem latic acid accumulation, accelerating $\mathrm{pH}$ change to neutral and favoring protein-degrading enzyme activity. The $\mathrm{pH}$ value of fish intended for human consumption must be lower than 7 . The $\mathrm{pH}$ value of marketed tambaquis varies from 6.2 to 6.5 (Mendes, 2013) and increases with quality loss. Other studies, however, suggest that $\mathrm{pH}$ is not an efficient indicator of fish quality if analyzed alone (Fontes et al., 2007). Indeed, in the present study, evaluation of this parameter alone is not sufficient to indicate the most suitable slaughter method, since groups killed by asphyxia or hypothermia exhibited a low variation in $\mathrm{pH}$ values. Nevertheless, fish slaughtered immediately after transport showed $\mathrm{pH}$ above 6.5 at 28 days post-slaughter, whereas fish allowed to recover from transport stress obtained this level after 49 days of storage.

Batista et al. (2004) observed that farmed matrinxãs kept in ice initially exhibited lower $\mathrm{pH}$ values, increasing after 6 days. Almeida et al. (2006) observed pH between 6.07 and 6.66 in farmed tambaquis kept in ice for 43 days, with a small variation in the first days of storage and a significant increase after 19 days. Similar results were also observed by Concollato et al. (2016) and Castro et al. (2016). The increase in $\mathrm{pH}$ is likely related to the accumulation of basic substances such as ammonia and trimethylamine, which are produced by microorganism development in fish (Huss, 1998).

The total content of basic volatile compounds in fish is usually low in the early days of storage, increasing rapidly with loss in fish quality (Huss, 1998), as observed in fish from all the study groups. Tambaquis slaughtered by asphyxia, however, exhibited higher TVB-N than those killed by hypothermia. In all the groups, TVB-N increased moderately until 14 days post-slaughter, and although this increase was gradual until 42 days, it was higher in the group killed by asphyxia, showing the disadvantage of 
this method. Thereafter, TVB-N in fish killed by post-transport hypothermia was close to that of fish killed by asphyxia, and at 49 days fish from the three groups (Tr/Asph, Tr/Hyp and Rc/Asph) were unsuitable for consumption, exhibiting TVB-N greater than $30 \mathrm{~g} \mathrm{~kg}^{-1}$, the limit determined by RIISPOA (Brasil, 2001). On the other hand, fish slaughtered post-recovery by hyperthermia were still acceptable since they contained TVB-N $25 \mathrm{~g} \mathrm{~kg}^{-1}$. Almeida et al. (2006) report acceptable TVB-N values in $2.5 \mathrm{~kg}$ tambaquis 37 days after slaughter by post-harvest hypothermia, but after 46 days of ice storage, the mean TVB-N value was $35 \mathrm{~g} \mathrm{~kg}^{-1}$. Mendes (2013) found a TVB-N variation in tambaquis, increasing from 15.14 to $32.19 \mathrm{~g} \mathrm{~kg}^{-1} \mathrm{TVB}-\mathrm{N}$ at 35 days of ice storage, similar to that reported by Almeida et al. (2006).

Sensory analysis showed that the quality of the tambaquis slaughtered by asphyxia was lower after 7 to 21 days of storage. After 28 days, fish killed by hypothermia after transport (Tr/Hyp) exhibited higher scores in sensory analysis than those killed by asphyxia after recovery (Rc/Asph). Thereafter, scores increased gradually in all treatments, until the end of observations.

Considering the stress indicators evaluated and tambaqui meat quality, a period of recovery from transport stress and the use of hypothermia as a slaughter method are procedures that preserve quality and extend the shelf life of farmed tambaquis, delaying rigor mortis resolution by nearly 20 days and promoting better storage conditions.

\section{Conclusions}

The applicability of the recommendations in the field must be further investigated, but the findings of the present study contribute to the adoption of practices that control raw matter quality and promote humanitarian management.

\section{Acknowledgements}

To CNPq (Protocol 483007/11-0), EMBRAPA (Protocol 02.13.09.001.00.06.003), FINEP (Project DARPA/SEPA/SEPROR), FAPEAM (MSc Scholarship for J.M. Maia and PAPAC 062.00890.2014) and the Aquaculture Station of INPA (Manaus, AM).

\section{References}

Acerete, L., Reig, L., Alvarez, D., Flos, R., \& Tort, L. (2009). Comparison of two stunning/slaughtering methods on stress response and quality indicators of European sea bass (Dicentrarchus labrax). Aquaculture (Amsterdam, Netherlands), 287(1-2), 139-144. http:// dx.doi.org/10.1016/j.aquaculture.2008.10.012.

Almeida, N. M., Batista, G. M., Kodaira, M., \& Lessi, E. (2006). Alterações pós-mortem em tambaqui (Colossoma macropomum) conservados em gelo. Ciência Rural, 36(4), 1288-1293. http://dx.doi.org/10.1590/ S0103-84782006000400038.

American Public Health Association. (1980) Standard methods for determinations of water and wastes (20th ed.). Washington: Joint Editorial Board.

Batista, G. M., Lessi, E., Kodaira, M., \& Falcão, P. T. (2004). Postmortem biochemical changes in matrinxã, Brycon cephalus (Günther, 1869) coming from the fish, kept in ice. Ciência e Tecnologia de Alimentos, 24, 573-581. http://dx.doi.org/10.1590/S0101-20612004000400016.
Bito, M., Yamada, K., Mikuno, Y., \& Amano, K. (1983). Studies on rigor mortis of fish - I. Difference in the mode of rigor mortis among some varieties of fish by modified Cutting's method. Bulletin Tokai Regional Fisheries Research Laboratory, 109, 89-96.

Boggess, T. S., Heaton, E. K., Shewfelt, A. L., \& Parvin, D. W. (1973). Techniques for stunning channel catfish and their effects on product quality. Journal of Food Science, 38(7), 1190-1193. http://dx.doi. org/10.1111/j.1365-2621.1973.tb07235.x.

Brasil. Ministério da Agricultura, Pecuária e Abastecimento. Departamento Nacional de Inspeção de Produtos de Origem Animal. (2001). Regulamento da Inspeção Industrial e Sanitária de Produtos de Origem Animal - RIISPOA: pescados e derivados (cap. 7). Brasília.

Castro, P. L., Lewandowski, V., Souza, M. L. R., Coradini, M. F., Alexandre, A. C., Sary, C., \& Ribeiro, R. P. (2016) Effect of different periods of pre-slaughter stress on the quality of the Nile tilapia meat. Food Science and Technology (Campinas), ahead of print.

Concollato, A., Olsen, R. E., Vargas, S. C., Bonelli, A., Cullere, M., \& Parisi, G. (2016). Effects of stunning/slaughtering methods in rainbow trout (Oncorhynchus mykiss) from death until rigor mortis resolution. Aquaculture (Amsterdam, Netherlands), 462, 74-79. http:// dx.doi.org/10.1016/j.aquaculture.2016.06.009.

Erikson, U., Lamboij, B., Digre, H., Reimert, H. G., Bondo, M., \& Van Dervis, H. (2012). Conditions for instant electrical stunning of farmed Atlantic cod after dewatering maintenance of unconsciousness, effects of stress, and fillets quality: a comparison with AQUI-S ${ }^{\text {sum. }}$. Aquaculture (Amsterdam, Netherlands), 324, 135-144. http://dx.doi. org/10.1016/j.aquaculture.2011.10.011.

Freitas, R. S., Boijink, C., Muniz, A. W., Dairiki, J., \& Inoue, L. A. K. A. (2014). Qualidade da água e perspectivas para o gerenciamento ambiental dos cultivos de tambaqui no município de Rio Preto da Eva, AM. Scientia Amazonia, 3, 116-126.

Fontes, M. C., Esteves, A., Caldeira, F., Saraiva, C., Vieira-Pinto, M., \& Martins, C. (2007). Estado de frescor e qualidade higiênica do pescado vendido numa cidade do interior de Portugal. Arquivo Brasileiro de Medicina Veterinária e Zootecnia, 59(5), 1308-1315. http://dx.doi.org/10.1590/S0102-09352007000500031.

Gatica, M. C., Monti, C., Gallo, C., Knowles, T. G., \& Warriss, P. D. (2008). Effects of well-boat transportation, on muscle $\mathrm{pH}$ and onset of rigor mortis of Atlantic salmon. The Veterinary Record, 163(4), 111-116. PMid:18660520. http://dx.doi.org/10.1136/vr.163.4.111.

Gatica, M. C., Monti, G. E., Knowles, T. G., \& Gallo, C. B. (2010). Effects of crowding on blood constituents and flesh quality variables in Atlantic salmon (Salmo salar). Archivos de Medicina Veterinaria, 42(3), 187-193. http://dx.doi.org/10.4067/S0301-732X2010000300010.

Gentzkow, C. J., \& Masen, J. M. (1942). An accurate method for the determination of blood urea nitrogen by direct nesslerization. The Journal of Biological Chemistry, 143, 531-544.

Gomes, L. C., Roubach, R., Araújo-Lima, C. A. R. M., Chiparri-Gomes, A. R., Lopes, N. P., \& Urbinati, E. C. (2003). Effect of fish density during transportation on stress and mortality of juvenile tambaqui (Colossoma macropomum). Journal of the World Aquaculture Society, 34(1), 76-84. http://dx.doi.org/10.1111/j.1749-7345.2003.tb00041.x.

Harrower, J. R., \& Brown, C. H. (1972). Blood lactic acid: a micromethod adaptes to field collection of microliter samples. Journal of Applied Physiology, 32(5), 224-228. PMid:5038862.

Herrero, A. M., Huidobro, A., \& Careche, M. (2003). Development of a quality index method for frozen hake (M. capensis and M. paradoxus). Journal of Food Science, 68(3), 1086-1092. http:// dx.doi.org/10.1111/j.1365-2621.2003.tb08293.x. 
Huss, H. H. (1998). El pescado fresco: su calidad y câmbios de su calidad (Documentos Tecnicos de Pesca, No. 348). Roma: FAO.

Instituto Adolfo Lutz. (2008) Normas analíticas do Instituto Adolfo Lutz: métodos químicos e físicos para análises de alimentos (4th ed.). São Paulo: Instituto Adolfo Lutz.

Iwama, G., Afonso, L., Todgham, A., Ackerman, P., \& Nakano, K. (2004). Are hsps suitable for indicating stressed states in fish? The Journal of Experimental Biology, 207(Pt 1), 15-19. PMid:14638828. http:// dx.doi.org/10.1242/jeb.00707.

Knowles, T. G., Brown, S. N., Warriss, P. D., Lines, J., Tinarwo, A., \& Sendon, M. (2008). Effect of electrical stunning at slaughter on the quality of farmed turbot (Psetta maxima). Aquaculture Research, 39(16), 1731-1738. http://dx.doi.org/10.1111/j.1365-2109.2008.02049.x.

Larsen, E. P., Heldbo, J., Jespersen, C. M., \& Nielsen, J. (1992). Development of a standard for quality assessment on fish consumption. In H. H. Huss, M. Jacobsen \& J. Liston (Eds.), Quality assurance in the fish industry (pp. 351-358). Amsterdam: Elsevier.

Lowry, D. H., Rosenbrough, N. J., Farr, A. L., \& Randall, R. J. (1951). Protein measurement with folin phenol reagent. The Journal of Biological Chemistry, 193(1), 265-275. PMid:14907713.

Mendes, J. M. (2013). Influência do estresse no pré-abate e durante o abate na qualidade do tambaqui (Colossoma macropomum) procedente de piscicultura (Dissertação de mestrado). Programa de Pós-graduação em Agricultura no trópico úmido, Instituto Nacional de Pesquisas da Amazônia, Manaus.

Mendes, J. M., Inoue, L. A. K. A., \& Jesus, R. S. (2015). Influència do estresse causado pelo transporte e método de abate sobre o rigor mortis do tambaqui (Colossoma macropomum). Brazilian Journal of Food Technology (Campinas), 18(2), 162-169. http://dx.doi. org/10.1590/1981-6723.1115.

Oliveira, P. R. C., Fo, Girao, P. J. M., Melo, M. P., \& Viegas, E. M. M. (2015). Indicators of stress in tilápia subjected to different stunning methods. Boletim do Instituto de Pesca, 41, 335-343.

Pate, E. F., \& Brokaw, C. J. (1980). Cross-bridge behaviour in rigor muscle. Biophysics of Structure and Mechanism, 7(1), 51-63. PMid:7225522. http://dx.doi.org/10.1007/BF00538158.

Trinder, P. (1969). Determination of glucose in blood using glucose oxidase with an alternative oxygen acceptor. Journal of Clinical Pathology, 22, 158-161. PMid:5776547. http://dx.doi.org/10.1136/ jcp.22.2.158.

Viegas, E. M. M., Pimenta, F. A., Previero, T. C., Gonçalves, L. U., Durães, J. P., Ribeiro, M. A. R., \& Oliveira, P. R. C., Fo. (2012). Métodos de abate e qualidade da carne de peixe. Archivos de Zootecnia, 61, 41-50. 